THE GLOBAL ENVIRONMENT AND INTERNATIONAL LAW 
THIS PAGE INTENTIONALLY LEFT BLANK 


\section{THE GLOBAL}

ENVIRONMENT

AND

Joseph F. C. DiMento

INTERNATIONAL

LAW

ד্ $\begin{aligned} & \text { University of Texas Press } \\ & \text { Austin }\end{aligned}$ 
Copyright $\left({ }^{\circ} 2003\right.$ by the University of Texas Press

All rights reserved

Printed in the United States of America

First edition, 2003

Requests for permission to reproduce material from this work should be sent to Permissions, University of Texas Press,

P.O. Box 7819, Austin, TX 78713-7819.

(2) The paper used in this book meets the minimum requirements of ANSI/NISO Z39.48-I992 (RI997) (Permanence of Paper).

Library of Congress Cataloging-in-Publication Data

DiMento, Joseph F.

The global environment and international law / Joseph F. C.

DiMento.- Ist ed.

p. $\mathrm{cm}$.

Includes bibliograpical references and index.

ISBN 0-292-7 I620-6 (cloth : alk. paper)—ISBN 0-292-7I 624-9

(pbk. : alk. paper)

I. Environmental law. International. I. Title.

$\mathrm{K} 3585 . \mathrm{D} 542003$

34 I.7'62-DC2I

2002012296 
To

Donald N. Michael (in Memoriam) and

Joseph L. Sax 
I'm hopeful ... and this is important to us as a species ... we tend to do the right things when we get scared.

-Octavia Butler, novelist, New York Times interview, 1 January 2000 